\title{
Prevention of Crime in the Context of Ethno-Social Relations
}

\author{
Yerazak Manapovich Tileubergenov ${ }^{1}$, Serik Turlybekovich Tuleyev ${ }^{2}$ and Sharap \\ Seitkasymovich Saduakassov ${ }^{\top}$
}

${ }^{1}$ Kokshetau University named after Sh.Ualikhanov, Kazakhstan

${ }^{2}$ Specialized Administrative Court of Kokshetau City, Kazakhstan

\begin{abstract}
In this article, the authors examine the importance of crime prevention in the context of ethno-social relations. The problem of interethnic interaction is extremely important for any multi-ethnic state. Interethnic contacts are not always positive, which is why the problem of interethnic conflicts is one of the most important and relevant areas of research in modern social sciences. Ethnic conflicts objectively lie on the line of differences between ethnic groups, the subjective basis of which is ethnic identity. The theory of crime and the ways of its prevention is investigated on the basis of the program-target approach. Throughout the research, the authors come to the conclusion that in order to overcome the crime, it is vital to target the most vulnerable groups and implements special programs. As a result of the targeting approach, the ethno-social tensions could be overcome and minimize the proliferation of crime.
\end{abstract}

Keywords: Crime, prevention, ethno-social relation research, law, society.

\section{INTRODUTION}

Being a social and legal phenomenon, crime by its origin and causes is closely linked to almost all aspects of the functioning of society. In order to reduce the impact of this negative process on people's lives and the existence of the state, numerous health measures are required. All these actions should be considered as a manifestation of the regulation of relations that have developed in society (Theoretical foundations of crime prevention, 1977).

There is another definition of the theory of crime prevention-this is the doctrine of a system of means that, takes into account the data of other Sciences, and in particular other sections of criminology, that should be implemented in order to limit the social phenomenon of crime (Criminology. Textbook, 1995).

The crime prevention system is designed to make this a reality. It includes a set of preventive measures aimed at solving this problem, as well as performing its inherent functions of interaction between elements of the system of subjects of crime prevention. These include: state bodies, public organizations, officials and citizens who exercise "their rights and obligations in interrelation and coordination in time and space" (Bafia E, 1983).

\section{LITERATURE REVIEW}

Crime prevention and prevention is not carried out blindly, not by touch, it must be purposeful. In this

*Address correspondence to this author at the Specialized Administrative Court of Kokshetau City, Kazakhstan; E-mail: etm61@mail.ru context, many legal scholars, sociologists, psychologists, political scientists and representatives of many other scientific fields are conducting research and development (Yuldoshev, et al., 2018). To date, a whole direction has been formed in criminology, which has received the name "theory of crime prevention" (Criminology: textbook, 1995; The course of Soviet criminology, 1986). Crime prevention can be defined as a body of knowledge about the activities of improving public relations in order to:

- $\quad$ identify and neutralize the causes of crime and the conditions that accompany it;

- identification and neutralization of the phenomena and processes that cause the commission, growth and spread of certain forms and types of crimes;

- $\quad$ factors affecting the formation of antisocial traits in a certain category of persons;

- influence on the conditions of their life and upbringing, elimination of specific conditions that lead to the commission of crimes by individuals;

definition of forms and methods of crime control (Criminology: textbook, 1995).

Theoretical research contributes to the solution of the most important socially significant task to reduce the level of crime, to reduce in every possible way the spheres of influence of its causes, to make sure that the living conditions of people contribute to the improvement of the criminological situation. It is necessary to prevent tension and conflicts in relations 
between citizens, their associations, collections, social, national, religious groups, which are accompanied by violations of criminal legislation.

\section{METHODOLOGY}

\section{The Crime Prevention Overview}

The crime prevention system performs a number of functions. One of the most important among them is the regulatory one. It is one through creating conditions that are favorable for resolving all contradictions and even conflicts that arise between citizens within the limits of law. The protective function is that this system protects the rights and freedoms of citizens, which is very important in relation to crime prevention (Tileubergenov et al., 2017).

The educational function seems to be the most significant if we are talking about crime caused by ethno-social factors. After all, only a change in people's consciousness, overcoming the complex of intolerance and hostility to unfamiliar peoples, religions, and beliefs can become the true main reason from prevention of such offenses. Promotion of humanism, ideas of equality of all humans a combination of persuasion and correction of the behavior of citizens can create the ground for mutual understanding of people and will ensure the formation of a truly safe society.

Among the subjects of crime prevention, local groups can be identified depending on the functions that they perform. At the same time, this division is very conditional, due to the fact that, United by a single goal, state bodies, public organizations, officials, and citizens are obliged to act together and at a certain time, under certain circumstances, closely cooperating with each other (Tileubergenov et al., 2016).

\section{The Theory and Practice}

In theory and practice, there are usually three groups of subjects of crime prevention. The first group includes those that directly lead to individual prevention. The second group includes entities that carry out prevention in the course of their control and law enforcement functions. The third group consists of entities that are primarily engaged in the management or coordination of crime prevention activities (Borodin SV, 1990).

Subjects of direct crime prevention conduct individual preventive work. They influence the conditions of upbringing and everyday life of an individual. They are quite capable of removing criminal situations, preventing crimes. Subjects belonging to this group can make sure that anti-social acts caused by ethno-social motives do not develop into gross and dangerous offenses. It is they who can understand the essence of people's misconceptions, largely eliminate the causes of tension in interpersonal communication, and prevent the recurrence of a crime.

This group includes above all the family. They form the personality of each citizen. The creation of prosperous economic, housing, and moral conditions in these primary cells of society contributes to the fact that both parents and children will be able to positively assess the world around them, and not feel hostility to people of other nationalities and faiths. The most significant in this regard are well-off families that have emerged from ethnically mixed marriages, where parents have a high level of education and professional qualifications. However, the family has the most favorable impact on the individual in close contacts with educational institutions for children, local government departments that are engaged in crime prevention for both adults and minors (Bafia E, 1983).

Stability of the situation of families and a peaceful and friendly environment in them are very important for preventing many types of offenses, including those related to ethno-social factors. This is especially significant, since, according to crime statistics, a significant part of crimes is committed on so-called domestic grounds (Bafia E, 1983).

\section{The Social Groups Fragmintation and Research}

In labor and educational collectives, as well as in the environment of neighbors in the house, yard, block, street, village and village, a kind of moral and psychological climate is created that can serve the cause of crime prevention. Managers of enterprises and educational institutions who are objectively interested in stabilizing the situation are responsible for improving relations among their colleagues and wards. The solution to this problem in the ethno-social sphere is facilitated by the fact that among the members of labor and educational collectives, residents of local spaces, there may be people of different nationalities who somehow have to establish relations with each other. Familiarity with native speakers of different cultures and worldviews ultimately leads to the establishment of normal service and neighborhood relations.

This group includes law enforcement agencies. The most active work on the direct prevention of crimes 
should be carried out by the police. Its employees, guided by the requirements of legislation, job descriptions, based on knowledge and professional experience, are required to work with the population, promptly identify the most dangerous situations and take urgent preventive measures, as well as prevent offenses (Shapieva OG, 1997).

Internal Affairs agencies, the Prosecutor's office, the court, special state security agencies, as well as nondepartmental control bodies should be included in the number of entities that carry out crime prevention in the performance of control and law enforcement functions. Using administrative, operational-investigative, criminal - procedural and other means of activity, the internal Affairs bodies monitor public order, perform functions for the prevention, detection and disclosure of offenses. Their tasks include the implementation of inquiry, preliminary investigation, and execution of punishment (Kulikov and Sheleg, 2016). the Specific role of law enforcement agencies in the prevention of crimes on ethnic and social grounds is that their employees must largely work in close contact with the population, and must exert a stabilizing influence on citizens.

In dangerous situations, as well as in the presence of even the slightest possibility of their occurrence, preventive measures should be taken by special state security agencies, since these situations are caused by the destructive nature of ethnic and social conflicts and are needed to be prevented at the stage of origin. The actions of special services are especially necessary when it comes to fighting organized crime (and criminal communities are often covered by nationalist and religious slogans), as well as the risk of committing terrorist acts.

Non-departmental control bodies are called upon to monitor compliance with the legislation within their competence. The prevention of crimes caused by ethno-social factors is primarily facilitated by the activities of a number of inspections: environmental protection, compliance with legislation in the field of maternal and child health, industrial safety, etc. The most effective way to prevent this type of crime would be to create a body to monitor the observance of citizens ' rights. Unfortunately, the formation of a state structure that should work closely with public human rights organizations is still at an early stage in many CIS countries.

The entities engaged in the management of the prevention of crimes - the bodies of representative and
Executive authorities of all levels. They, together with the Prosecutor's office, should manage the process of improving the criminological situation in the country and in each of its parts, and carry out fruitful international cooperation with other States in this area (Bystrokin Al, 2017).

Representative and Executive authorities, paying great attention to crime prevention, depending on their level, may place one or another emphasis on various aspects of this activity. A large amount of work is to be done by local authorities and self-government. Taking into account the specific conditions of a particular district, city, or other locality, it is relatively easy for them to build the foundations of preventive anti-criminal activities, organize prevention, combat deviant behavior, and carry out preventive suppression of offenses. It is local authorities that can successfully resist the undesirable development of a situation fraught with open conflicts caused by ethno-social factors. This is due to the fact that these contradictions arise at the local level, and here their suppression or settlement is most painless and effective.

Local authorities and self-governments need to issue legal acts that regulate crime prevention. They should take organized measures to liberalize all available resources to create a crime-free environment. Coordinating the efforts of all necessary participants in this activity, providing them with the necessary resources, the authorities are obliged to monitor compliance with the relevant legislation. The whole package of measures should be permanent, systematic, without periods of recessions. A prerequisite for such work is to conduct it on the basis of comprehensive crime prevention plans.

Planning of measures to prevent both crimes in General and those caused mainly by ethnosocial factors should be based on reliable forecasts of the criminological situation in the country, its part, the given area, as well as - specifically - on forecast data concerning the type of socially dangerous acts under consideration (Ziberova and Ziberov, 2017).

\section{Methodological Forecast}

It seems that in the future the state of crime will be based mainly on the analysis of the factors that affect these negative social and legal phenomena. It can be quite definitely stated that crimes related to ethnosocial factors have the greatest scale and are characterized by the greatest severity during periods of 
political instability, environmental devastation, and mass movements of refugees and internally displaced persons. Naturally, this type of crime becomes disastrous with the General rise in the crime rate. Criminal acts caused by contradictions on an ethnosocial basis become especially noticeable when there is little daily, painstaking and consistent prevention, insufficient educational work among the parts of the population most exposed to national ideology, religious and social intolerance.

The goals of fighting crime are diverse. These include the most common (especially reducing the level of crime in General, reducing the severity of criminal acts, etc.) and private (a reduction in crime by type of crime, its latency, spread among different segments of the population, the elimination of most crime areas in cities, areas, parts of the country, combating international crime, etc.).

In the scenarios made elements of the target forecast, which adjust the expected future picture, as would "improve" it.

The degree of "favorability" is determined by how successfully you can influence the many factors that determine the parameters of crime. The success of such activities depends to a large extent on the availability of the necessary resources in society as a whole, and the crime prevention system in particular.

At the same time, it should be taken into account that the impact on a significant number of factors that cause crime can be mainly indirect.

This fully applies to ethno-social factors. To influence this aspect of crime, it is necessary to ensure free and voluntary contacts between people of different nationalities, social groups and faiths, as well as many other things. It is important to establish the rule of law in relation to the offense, to guarantee the implementation of human and civil rights and freedoms. Only simultaneously with these conditions can actions of representative and Executive authorities and other subjects of crime prevention could be carried out in the field of prevention of offenses based on ethnic and social contradictions.

Based on the forecast of the criminological situation, comprehensive programs are being prepared to combat crime (Avdeev, et al. 2019). They reflect the analysis of the most significant problems in the fight against crime and indicate the activities developed taking into account the number of resources that can be allocated to solve the tasks set. The theory of crime prevention considers the problem of reducing the scale of this negative phenomenon as a process of solving a number of complex and interrelated tasks. The latter form a hierarchical system, the elements of which differ in the degree of community, social significance, and the influence of various aspects of people's lives.

The first task is the broadest in terms of coverage of the affected phenomena-the impact on the causes of crime as such, and through this - on its characteristics. The most important of them should be considered the level of Commission of criminal offenses, the state of their types, changes in these indicators over time, and the distribution of dangerous illegal acts by individual districts, cities, and their regions. This task is called social prevention.

The second data is more specific. It boils down to reducing the level of crime by its types as much as possible, preventing the development of forms of deviant behavior, and reducing violations of criminal legislation in various spheres of public life. It is important to reduce crime in all social groups, but especially among young people, women, as well as in various groups of the population that are usually classified as a "risk group". Thus, we are talking about criminological prevention, the solution of the third task provides for the prevention of criminal acts committed by certain citizens and is an individual criminological prevention.

In the legal literature, there is a tradition to associate with each of these tasks a certain type of activities necessary for their solution. The first task involves the use of funds of the most General nature, which relate to a wide range of living conditions for all categories of the population. Social, economic, and political measures should pursue the main goal of creating an environment that would contribute to improving the functioning of society, reducing tensions in interpersonal relations, and organizing people's activities aimed at creative work and establishing a state governed by the rule of law. Some authors call this set of measures the formation of social life of people (Pelevin, et al. 2018).

\section{RESULTS}

\section{An Importance of Reducing Tension in the Ethno- Social Sphere}

The formation of an atmosphere of social stability, the development of a healthy economic environment, 
the development of cooperation between the economies of countries and their individual regions, the strengthening of interstate relations, the dissemination of knowledge about other peoples - all this can lead to smoothing out interethnic contradictions, reducing tension in the ethno-social sphere.

The steps required for the solution of the second task are more specific. They are designed for changes in conditions in certain areas of public life, among certain population groups. Therefore, their content is determined by the specific situation in the social environment.

It is important to identify the least well-off groups of the population, in which or between which tensions in the ethno-social sphere reach particularly dangerous proportions. Measures should be based on the study of the causes of the current unfavorable situation and reducing the impact of these factors on the criminological situation. Careful differentiation of efforts is required, taking into account the national, demographic, psychological, cultural, religious, and social characteristics of population groups. Among other activities, an important role should be given to those that are designed to create an environment of peace, trust, lack of prejudice and distrust between representatives of various communities, categories of residents of certain localities.

In this case, it is possible to remove many of the motives, conditions and situations that contribute to the Commission of crimes. Individual preventive measures are aimed at solving the third problem. They are conducted in accordance with the emerging need to transform the personalities of individuals. It is possible to develop special social programs. In the course of their formation, legal and moral norms are determined. Crime prevention is aimed at their observance in society (Pelevin SI, 2018).

\section{The Prevention of Anti-Social and Unethical Behaviour}

It is also possible to work individually with citizens who differ in different degrees of intransigence in issues of interethnic relations. Mitigating feelings of hostility to representatives of other peoples requires long-term and systematic work, erudition, remarkable knowledge, talent, and resourcefulness from law enforcement officials.

These and other measures can deter citizens from committing crimes, isolate and deprive members of criminal communities of the moral and physical support of their former associates.

The crime prevention system includes a well-known combination, interaction of prevention subjects, means of achieving the desired goal, depending on the abovementioned tasks, the specific conditions in which they are to be solved, as well as on the structure and scale of illegal socially dangerous acts specific to a given locality or country. At the same time, it is important to adhere to certain principles of crime prevention (Tileubergenov EM, 2016). These ideas express the main ideas of the state's policy in the field of combating this anti-social phenomenon.

The principle of program reconstruction of society is based on the assumption that it is possible to reduce the level and danger of crime by changing the social environment, purposefully influencing it. According to proponents of this approach in criminology, the number and severity of dangerous acts will decrease as a result of a large set of socially significant events. At the same time, they themselves critically assess the reality of such a prospect- "this hypothesis was not confirmed by practice, but it had a negative impact (as, indeed, too optimistic estimates of crime reduction), not contributing to the mobilization of forces to fight crime" (Avdeev, et al., 2019).

Similar in content, but providing for more specific actions is the principle of stimulating social means to accelerate socialization (Sergevnin et al., 2015). If we assume that the process of socialization is, first of all, the process of social education of a person, then the ability of an individual to live in peace with other people is put in the first place. With regard to the sphere of ethno-social relations, this way of solving the problem of reducing the crime rate provides for the desire and realized desire of a person to maintain normal civilized relations with representatives of social groups, other nationalities, cultural communities, and confessions that are far from him. It is essential to stimulate the lawabiding behavior of every citizen, as well as the purposeful impact of the responsible authorities on the social environment, which would not arouse feelings of dissatisfaction, aggressiveness, and social disability among the population.

\section{The Importance of the Principles of Public Condemnation of Criminal Behavior}

The principle of public condemnation of criminal behavior provides the breeding ground for the creation 
of a moral and psychological atmosphere among citizens that would make violations of legal requirements unattractive. It is necessary to form public opinion about the inadmissibility of criminal acts. The most rational measures that contribute to achieving this state are the dissemination of objective information about the requirements of the law, the sanctions applied to violators, and all kinds of incentives for forces that seek to improve the situation in society, reduce the number and severity of criminal actions. It is of great importance to create a common mood to ensure the stability of relations between people of different nationalities, to strengthen the sense of personal and collective security. To implement this principle, it is necessary to conduct educational, promotional and organizational activities.

It is very important for carrying out preventive activities to adhere to the principle of the equacy of methods and means of preventing a criminal situation. Since there are certain functional links between criminological factors and their corresponding criminal manifestations that have been largely studied to date, it is possible to assess what are the most rational means of combating crime for each specific case.

It is obvious that it is quite logical to conduct a typology of criminological situations and establish appropriate responses of law enforcement agencies. It is also useful to develop targeted programs to respond to certain combinations of criminal conditions. They appear to be particularly promising in those cases where the destructive behavior is influenced by social factors. The success of the fight against crime is largely determined by the type and scale of the selected activities. It is important that they are neither excessive nor insufficient.

\section{CONCLUSION}

The authors come to the conclusion that the ethnosocial sphere is a special environment of social relations, which differs in many ways. In criminological terms, one of its characteristic features is a fairly high latency of crimes. This creates a sense of impunity for violators and encourages them to commit new crimes based on their belief in "their" rightness. That is why it is important to implement the principle of a high level of crime detection.

It seems to us that the solution to the problem of crime prevention lies in the way of a comprehensive impact on the levels that cause it, especially if it concerns the ethno-social aspect of such a negative phenomenon. Only a deep analysis of the many aspects of cause-and-effect relationships that cause criminal acts, the study of mechanisms that reduce their number, severity and spread across the country, make it possible to successfully improve the criminological situation.

\section{REFERENCES}

Avdeev, V.A. et al. 2019. Technologies of the Legal Educational Process: The Main Directions of Improvement in the Conditions of Globalization. International Journal of Civil Engineering and Technology 10(02): $1554-1560$.

Avdeev, V.A., et al. 2019. Technologies of the legal educational process: the main directions of improvement in the conditions of globalization. International Journal of Civil Engineering and Technology (IJCIET)10(02): 1554-1560.

Bafia E. Problems of criminology. Dialectics of the criminal situation. Textbook / E. Bafiya. - M., 1983. - 22 p.

Bafia E. Problems of criminology. Dialectics of the criminal situation. Textbook / E. Bafiya. - M., 1983. -117 p.

Bafia E. Problems of criminology. Dialectics of the criminal situation. Textbook / E. Bafiya. - M., 1983. -130 p.

Borodin S. V. Fighting crime: a theoretical model of a comprehensive program. Monograph / S. V. Borodin. - M., 1990. -248 p.

Bystrokin A. I. Counteraction to ethnic crime in the Russian Federation /Investigation of crimes: problems and ways to solve them. 2017. No. 1 (15). pp. 9-12.

Criminology.Textbook. - M., 1995. - 106s.

Criminology: textbook. - M., 1995. - 462 p.

Kulikov A.V., Sheleg O. A. Influence of ethnic differences and illegal migration on the state of crime in Russia //Bulletin of the Kaliningrad Branch of the St. Petersburg University of the Ministry of Internal Affairs of Russia. 2016. No 3(45). pp. 1721.

Pelevin, S.I., et al. Problem of technogenic society dynamics under the conditions of contemporaneity. International journal of Civil Engineering and Technology. 2018, 9(11), pp. 24372443.

Pelevin, Sergei Igorevich; Tileubergenov, Yerazak Manapovich y Vasiliev, Alexey Mikhailovich. Socio-economic modernization of technogenic society: background and development. Revista Inclusiones Vol: 7 num Especial (2020): 300-311.

Pelevin. S.I. The participation of youth of western countries in the political life of the society. The youth in the political life of the society. International journal of Civil Engineering and Technology. 2018, 9(11), pp. 2226-2233.

Sergevnin, V.A., Avdeev, V.A., and Avdeeva, O.A. 2015 Harmonization of Russian Correctional Policy in the Field of Sentencing and the Execution of Punishment. Criminology Journal of Baikal National University of Economics and Law 9(1): $78-93$.

https://doi.org/10.17150/1996-7756.2015.9(1).78-93

Shapieva O. G. Moral and legal socialization of the individual: dis. ... doctor of law: 12.00.01 / O. G. Shapieva.- M., 1997.

Shestakov, D. A. criminology the Family: family conflict is a crime. Monograph / D. A. Shestakov. - M., 1996. - P. 182-183.

Sidorova, E.Z. et al. 2020. Safety Issues of the Russian Educational System, Journal of Advanced Research in Law and Economics, Volume XI, Spring, 1(47): 187- 195. https://doi.org/10.14505//jarle.v11.1(47).22

The course of Soviet criminology: crime prevention. - M., 1986. - 350 p. 
Theoretical foundations of crime prevention. - M., 1977. -256 p.

Tileubergenov, E.M. Theoretical problems of implementing achievements of natural and technical sciences into the criminal judical system. Journal of Advanced Research in Law and Economics, 2016. 7(1), pp. 132-139.

Tileubergenov, E.M., Pelevin, S.I., Vasiliev A.M., Ibraimov, D.A., The significance of the international social-labour standards in the national law, Man in India, Volume 97, Issue 4, 2017, Pages 249-261.

Tileubergenov, E.M., Pelevin, S.I., Vasiliev, A.A., Danilyanc, E.I., Political and legal defining the regulation of war in the hague convention of 1907, Journal of Advanced Research in Law and Economics, Volume 7, Issue 3, Summer 2016, Pages 672-677. https://doi.org/10.15405/epsbs.2016.05.25

Yuldoshev R. R., et al. Crime in Tajikistan (1991-2016): scientific and practical manual. - Dushanbe: KONTRAST Publishing House, 2018.- 360p.

Ziberova O. S., Ziberov S. V. Ethnic criminality in Russia // Proryvnye nauchnye issledovaniya: problemy, regularities, perspektivy. Proceedings of the VIII International Scientific and Practical Conference. Penza, 2017. pp. 204-206.

https://doi.org/10.6000/1929-4409.2021.10.98

(C) 2021 Tileubergenov et al.; Licensee Lifescience Global.

This is an open access article licensed under the terms of the Creative Commons Attribution Non-Commercial License (http://creativecommons.org/licenses/by-nc/3.0/) which permits unrestricted, non-commercial use, distribution and reproduction in any medium, provided the work is properly cited. 